\title{
Analysis of the Impact of Treasury Single Account on the Performance of Banks in Nigeria
}

\author{
Chukwudi J. Ogbonna, Harrison O. Amuji \\ Department of Statistics, Federal University of Technology, Owerri, Nigeria \\ Email: d_ogbonna59@yahoo.com,amujiobi@yahoo.com
}

How to cite this paper: Ogbonna, C.J. and Amuji, H.O. (2018) Analysis of the Impact of Treasury Single Account on the Performance of Banks in Nigeria. Open Journal of Statistics, 8, 457-467. https://doi.org/10.4236/ojs.2018.83029

Received: December 27, 2017

Accepted: June 4, 2018

Published: June 7, 2018

Copyright (C) 2018 by authors and Scientific Research Publishing Inc. This work is licensed under the Creative Commons Attribution International License (CC BY 4.0).

http://creativecommons.org/licenses/by/4.0/

\section{cc) (i) Open Access}

\begin{abstract}
In this study, we developed multivariate model for the study of the impact of treasury single account (TSA) on the performance of banks in Nigeria. From the study, we discovered that there was no significant difference between the period before and after the introduction of the TSA policy on the performance of banks in Nigeria. In Diamond Bank Nigeria Plc, we observed that there were negative relationships between liquidity ratio and capital adequacy with correlation coefficient of -0.093 ; liquidity ratio and credit to customers with correlation coefficient of -0.312 ; capital adequacy and credit to customers with correlation coefficient of -0.176 . On the other hand, from the analysis on first bank, we observed that there were both positive and fairly strong relationships between the liquidity ratio and capital adequacy with correlation coefficient of 0.626; negative relationship between liquidity ratio and credit to customers with correlation coefficient of -0.880 and finally, negative relationship between capital adequacy and credit to customers with correlation coefficient of -0.165 .
\end{abstract}

\section{Keywords}

Treasury Single Account, Multivariate Analysis, Liquidity Ratio, Capital Adequacy Ratio, Credit to Customer

\section{Introduction}

Treasury single account is a banking arrangement put in place to control multiple accounts created by ministries, departments and agencies, (MDAs). The primary objective of a TSA is to ensure effective aggregate control over government cash balances. The consolidation of cash resources through a TSA ar- 
rangement facilitates government cash management by minimizing borrowing costs. In the absence of a TSA, idle balances are maintained in several bank accounts. Until the introduction of TSA in Nigeria, MDAs which generate revenue, have the multiplicity of accounts in commercial banks, use part of the revenue generated to fund their operations and then remit the surplus to the federation account. As a result, agencies pay into government account what they deem fit. The result of this situation includes leakages of funds, embezzlement of public funds, and inability of a government to know the exact amount in its account [1]. All these stunted the growth of the economy. This is in contrast to the provision of the Nigerian Constitution which requires that all government revenue generation must be remitted into a single account. The constitution of the Federal Republic of Nigeria; section 80 (1) of 1999 requires that all government revenue be remitted in to a single account of Consolidated Revenue Fund (CRF). Without adherence to the constitution provisions, the Federal Government had been operating a fragmented banking arrangement with thousands of banks accounts in multiple banks.

There were speculations that the introduction of TSA will badly affect the operations of commercial banks in Nigeria. For TSA to work effectively there must be daily clearing of and consolidation of cash balances into the central account. TSA can cover all funds earmarked and budgetary accounts or even funds held in trust by government. All Ministries, Departments and Agencies are expected to remit their revenue collections to this account through the individual commercial banks who act as collection agents. But all monies collected by these banks will have to be remitted to the Consolidated Revenue Accounts with the $\mathrm{CBN}$ at the end of each banking day. Remita is the Central payment platform supporting the payments of Federal Government and MDAs under the TSA, as it is widely accepted and connected online to all the DMBs and sizeable number of Micro Finance Banks (MFBs) and Primary Mortgage Institutions (PMIs). TSA allows complete and timely information on government cash resources; improves appropriation control; improves operational control during budget execution; enables efficient cash management; reduces bank fees and transaction costs; facilitates efficient payment mechanisms; improves bank reconciliation and quality of fiscal data; lowers liquidity reserve needs. The custody of the TSA in Nigeria is with the central bank. However, the balances in commercial banks should be cleared every day and all government cash balances should be consolidated in one central account of the treasury at the central bank [2].

TSA issue did not start with president Buhari administration in Nigeria. Actually, the former President Goodluck Jonathan initiated the policy but could not implement it before he left office on 29 May 2015 [3]. Buhari administration in September 2015 ordered all ministries, departments and agencies (MDAs) to sweep their account balances with deposit money banks to a central pool with the Central Bank of Nigeria (CBN) [4]. In the year 2012, government ran a pilot scheme for a single account using 217 ministries, departments and agencies as a 
test case. The result of the pilot scheme saved Nigeria about 500 billion in frivolous spending. This report motivated the government to fully implement Treasury Single Account (TSA) and directives given to deposit money banks (DMB) to implement the technology platform that will help to accommodate the Treasury Singly Account Scheme. This enables the treasury to delink management of cash control at a transaction level [5] [6].

Treasury single account is a pool in which all government revenue is collected and controlled by the Central Bank of Nigeria, with the view to boost the economy and reduce corruption [7]. These researchers did an analytical work. They collected secondary data from CBN and analyzed it using the segmented simple linear regression where each of the parameters under consideration was analyzed separately. Multiple linear regression would have been a good model for their work. Multiple linear regression will aggregate the entire parameter under consideration in a single regression model to determine the overall effects of the parameters on the overall performance of the dependent variable (TSA). In their work, Treasury Single Account and economic performance in Nigeria were carried out and their result shows that the Treasury Single Account has a positive significant impact on the country's economic growth. Findings from their analysis show that about $99.12 \%$ of total variations in the Nigerian Economy are explained by the TSA indicators, and only $0.88 \%$ that is unexplained variations can be ascribed to other factors outside the model.

Treasury Single Account was introduced in Nigeria as a result of numerous corrupt practices that exist in the Country's public accounting system, lack of transparency and accountability [1]. The researcher holistically looked into the positive effect of implementation of TSA on the Economy, the public accounting system and the undesired consequences on the liquidity base and performance of banking sector in Nigeria. The researcher used primary source of data collection (through questionnaires) to collect data for his study among Management staff of the ten banks selected for the study. She used Chi-square as her test statistic in the analysis of the data. From the results obtained, it was confirmed that the implementation of Treasury Single Account in the public accounting system impacted negatively on the liquidity base and the performance of banking sector in Nigeria. But primary data through questionnaire is not adequate for this kind of research; rather, an empirical (secondary) data based on the performance of the banks should have been used to ascertain the actual performance of the banking sector under the introduction of TSA.

[6] was of the opinion that since the federal government of Nigeria has implemented Treasury Single Account (TSA) to properly manage the scarce financial resources at the federal level, the State Governments of Nigeria should have followed suit. The purpose of their study was to examine the benefits, challenges and prospects of adoption of Treasury Single Account (TSA) by State Governments in Nigeria. The researchers used survey design for their study and used purposive sampling, one of the primary methods of data collections, and in fact 
a non-probability sampling, in collecting the data for their study. But in a study of this nature, purposive sampling is not adequate as it does not give every member of the population equal chances of being included in the sample. A study of this nature also requires an empirical and secondary data instead of questionnaires as a means of data collection. However, from the result of the analysis, it was observed that, TSA adoption and full implementation by the state governments will be of great benefit even though there will be challenges in a short-run but the benefits in the long-run will definitely out-weight the challenges. The researchers opined that the State Governments of Nigeria should adopt and fully implement TSA for successful control and accountability of public funds. It was also observed in this research that the researcher miss applied T-test statistic to test for a large sample that was even above 100. The appropriate test statistic would have been Z-test statistic. We suggest that researchers should consult widely before embarking on analysis to avoid deceptions and the journals that accept such work should try to review the works properly before acceptance and publication for the interest of the reading public and the reputation of their journal.

\section{Methodology}

Multivariate data are data collected on several dimensions or characteristics of the same individual or item or experimental trial. To test for difference between mean vectors of two populations, Hotelling's $T^{2}$ statistic and $F$ statistic were used [8] [9]. In this paper, we are interested in three parameters namely liquidity ratio, capital adequacy and credit to customers. These are multivariate data from each bank considered in this paper. The data were collected from two commercial banks; Diamond and First bank Nigeria limited, Owerri Imo State.

We shall develop multivariate analysis model for the research since we are considering many dependent variables from each bank at the same time and their effects compared simultaneously, multivariate analysis provide the best model for such a problem. Multivariate statistics has the ability to use the few data from 2015 to 2017 from the banks when the TSA was introduced in combination with the large data from the banks on the same subject when TSA was not introduced. We shall determine the Hotelling's $T^{2}$ statistic; Mahalanobi's $D^{2}$ statistic and $F$ distribution for the problem. We shall also determine the multivariate distribution for the data and test the hypothesis that there was no significant difference on these parameters before and after the introduction of TSA against the alternative hypothesis which state the contrary. The test statistics are stated as follows:

$$
T^{2}=\frac{n_{1} n_{2}}{n_{1}+n_{2}} D^{2}
$$

where $T^{2}$ is as explained above; $n_{1}$ is the sample data from the respective banks before the introduction of TSA in Nigeria; $n_{2}$ is the sample data from the respec- 
tive banks after the introduction of TSA in Nigeria and $D^{2}$ is the Mahalanobi's $D^{2}$ statistic.

$$
D^{2}=\left(\bar{X}_{1}-\bar{X}_{2}\right)^{\mathrm{T}} S^{-1}\left(\bar{X}_{1}-\bar{X}_{2}\right)
$$

where $\left(\bar{X}_{1}-\bar{X}_{2}\right)^{\mathrm{T}}$ is the difference in the sample mean vector of the first and the second sample data; the superscript $\mathrm{T}$ denote the transpose of $T$; and $S^{-1}$ denote the inverse of dispersion matrix or the inverse of the variance covariance matrix.

$$
F_{c a l}=\frac{\left(n_{1}+n_{2}-p-1\right)}{p\left(n_{1}+n_{2}-2\right)} \cdot T^{2}
$$

where $F_{c a l}$ denote the value of $F$ distribution statistic calculated; $p$ denote the parameters being estimated and other notations retain their usual meanings as defined earlier.

$$
F_{\text {tab }}=F(\alpha) ; p,\left(n_{1}+n_{2}-p-1\right)
$$

where $F_{\text {tab }}$ denote $F$ tabulated, this is the value of $F$ as it is stated in the standard $F$ tables and $(\alpha)$ denote the level of significance under which we make our inference about the impact of TSA on banks' performance in Nigeria.

We shall determine the covariance and the correlation on the performance of banks in Nigeria before and after the introduction of TSA in Nigeria.

In trying to achieve the above, we shall state some hypothesis that should be tested as follows:

1) Ho: $\bar{X}_{1}=\bar{X}_{2}$ vs $\mathrm{H}_{1}: \bar{X}_{1} \neq \bar{X}_{2}$

Ho: denote the null hypothesis which says that there is no significant difference between the performance of banks in Nigeria before and after the introduction of TSA. Vs stand for versus; and $\mathrm{H}_{1}$ : stand for the alternative hypothesis which says that there is significant difference between the performance of banks in Nigeria before and after the introduction of TSA. Hypothesis is an assumption to be tested; it could be true or false. If it is true, we accept the null hypothesis and reject the alternative but if it is the contrary, we accept otherwise. We stated the hypothesis because there is a need for us to test whether there is a significant difference in the performance of banks before and after the introduction of TSA in Nigeria using the three indicators we referred to as parameters in this study or not. Null hypothesis (Ho) supports the assumption that there was no significant difference in the performance of banks before and after the introduction of TSA in Nigeria, while the alternative hypothesis $\left(\mathrm{H}_{1}\right)$ states the contrary.

2) We shall state the decision rule as follows:

Accept Ho: if $F_{c a l}<F_{t a b}$ and reject if otherwise. $F_{c a l}$ denotes the value of $F$ distribution calculated while $F_{t a b}$ denotes the tabulated value of F-distribution as it is stated in any standard $F$ statistical tables. The two values are used to make inference about the stated hypothesis.

We shall make conclusion as follows:

Since $F_{c a l}>F_{t a b}\left(F_{c a l}<F_{t a b}\right)$, we reject Ho (accept Ho) and conclude that there is 
significant (no significant) difference between the performance of banks in $\mathrm{Ni}$ geria before and after the introduction of TSA.

\section{Data Presentation and Analysis}

\subsection{Data Presentation}

Table 1 and Table 2 presented data on the liquidity ratio, capital adequacy ratio and credit to customers from the two commercial banks under consideration. In the data analysis below, we shall split data set in each table into two parts to reflect the period before and after the introduction of TSA in Nigeria.

\subsection{Data Analysis (Table 3, Table 4)}

Where $X_{1}=$ Liquidity Ratio; $X_{2}=$ Capital Adequacy Ratio; $X_{3}=$ Credit.

Table 1. Data on the financial operations of Diamond Bank Nigeria Plc.

\begin{tabular}{cccc}
\hline & \multicolumn{3}{c}{ Diamond Bank Nigeria Plc } \\
\hline Year & L.R. (\%) & C.A.R. (\%) & Credit (M) \\
\hline 2008 & 111.11 & 109.27 & 41.8 \\
2009 & 122.02 & 82.25 & 92.2 \\
2010 & 132.68 & 110.41 & 76 \\
2011 & 114.15 & 175.35 & 61.9 \\
2012 & 124.79 & 141 & 78.1 \\
2013 & 110.16 & 149.21 & 77.1 \\
2014 & 111.09 & 151.69 & 96.5 \\
2015 & 119.2 & 178.91 & 111.8 \\
2016 & 97.33 & 124.45 & 162.4 \\
2017 & 115.84 & 135.84 & 88.7 \\
\hline
\end{tabular}

Source: Diamond Bank Nigeria Plc.

Table 2. Data on the financial operations of First Bank Nigeria Limited.

\begin{tabular}{lccc}
\hline & \multicolumn{3}{c}{ First Bank Nigeria Limited } \\
\hline Year & L.R. (\%) & C.A.R. (\%) & Credit (M) \\
\hline 2007 & 108.831 & 30.7 & 222.2 \\
2008 & 137.63 & 69.7 & 476.4 \\
2009 & 118.64 & 47.19 & 752.2 \\
2010 & 121.03 & 31.8 & 1151.2 \\
2011 & 114.67 & 26.74 & 1366.8 \\
2012 & 110.46 & 22.45 & 1645.5 \\
2013 & 107.44 & 18.68 & 1841.4 \\
2014 & 109.6 & 20.05 & 2036.9 \\
2015 & 110.69 & 28.49 & 1594.8 \\
2016 & 110.83 & 25.26 & 1897.2 \\
2017 & 114.98 & 27.9 & 1298.5 \\
\hline
\end{tabular}

Source: First Bank Nigeria Limited. 


$$
\bar{X}_{D, o}=\left[\begin{array}{c}
118.00 \\
131.31 \\
74.81
\end{array}\right] ; \quad \bar{X}_{D, n}=\left[\begin{array}{c}
110.79 \\
146.40 \\
120.97
\end{array}\right]
$$

where $D=$ Diamond Bank Nigeria Plc; $o=$ Financial Operation before TSA (old); $n=$ Financial Operation after TSA (new) and $B=$ First Bank Nigeria Limited.

$$
\bar{X}_{D, o}-\bar{X}_{D, n}=\left[\begin{array}{c}
7.21 \\
-15.09 \\
-46.16
\end{array}\right]
$$

The dispersion matrix is stated as follows

$$
\left(n_{i}-1\right) S_{i}^{2}=\left[\begin{array}{ccc}
\sum x_{1}^{2}-n \bar{x}_{1}^{2} & \sum x_{1} x_{2}-n \bar{x}_{1} \bar{x}_{2} & \sum x_{1} x_{3}-n \bar{x}_{1} \bar{x}_{3} \\
\sum x_{1} x_{2}-n \bar{x}_{1} \bar{x}_{2} & \sum x_{2}^{2}-n \bar{x}_{2}^{2} & \sum x_{2} x_{3}-n \bar{x}_{2} \bar{x}_{3} \\
\sum x_{1} x_{3}-n \bar{x}_{1} \bar{x}_{3} & \sum x_{2} x_{3}-n \bar{x}_{2} \bar{x}_{3} & \sum x_{3}^{2}-n \bar{x}_{3}^{2}
\end{array}\right]
$$

where $n_{1}$ and $n_{2}$ respectively stand for the first and second samples respectively.

$$
\begin{aligned}
\left(n_{1}-1\right) S_{1}^{2} & =\left[\begin{array}{ccc}
449.28 & -735.92 & 210.77 \\
-735.92 & 6101.25 & -212.57 \\
210.77 & -212.57 & 2036.21
\end{array}\right] \\
\left(n_{2}-1\right) S_{2}^{2} & =\left[\begin{array}{ccc}
277.40 & 515.53 & -798.84 \\
515.53 & 1650.22 & -868.20 \\
-798.84 & -868.20 & 2839.47
\end{array}\right] \\
\left(n_{1}+n_{2}-2\right) S & =\left[\begin{array}{ccc}
726.68 & -220.39 & -588.07 \\
-220.39 & 7751.47 & -1080.77 \\
-588.07 & -1080.77 & 4875.68
\end{array}\right]
\end{aligned}
$$

The pooled dispersion matrix is

$$
S=\left[\begin{array}{ccc}
90.84 & -27.55 & -73.51 \\
-27.55 & 968.93 & -135.10 \\
-73.51 & -135.10 & 609.46
\end{array}\right]
$$

And the correlation coefficients between the parameters of interest are

Table 3. Data on the financial operations of Diamond Bank Nigeria Plc before TSA.

\begin{tabular}{cccc}
\hline \multicolumn{3}{c}{ FUTO Micro-Finance Bank } \\
\hline Year & L.R. (\%) $X_{1}$ & C.A.R. (\%) $X_{2}$ & Credit (M) $X_{3}$ \\
\hline 2008 & 111.11 & 109.27 & 41.8 \\
2009 & 122.02 & 82.25 & 92.2 \\
2010 & 132.68 & 110.41 & 76 \\
2011 & 114.15 & 175.35 & 61.9 \\
2012 & 124.79 & 141 & 78.1 \\
2013 & 110.16 & 149.21 & 77.1 \\
2014 & 111.09 & 151.69 & 96.5
\end{tabular}


Table 4. Data on the financial operations of Diamond Bank Nigeria Plc after TSA.

\begin{tabular}{cccc}
\hline \multicolumn{4}{c}{ Diamond Bank Nigeria Plc } \\
\hline Year & L.R. (\%) $X_{1}$ & C.A.R. (\%) $X_{2}$ & Credit (M) $X_{3}$ \\
\hline 2015 & 119.2 & 178.91 & 111.8 \\
2016 & 97.33 & 124.45 & 162.4 \\
2017 & 115.84 & 135.84 & 88.7 \\
\hline
\end{tabular}

$$
\begin{aligned}
& \rho_{1.2}=\frac{-27.55}{\sqrt{90.84 \times 968.93}}=-0.093 \\
& \rho_{1.3}=\frac{-73.51}{\sqrt{90.84 \times 609.46}}=-0.312 \\
& \rho_{2.3}=\frac{-135.10}{\sqrt{968.93 \times 609.46}}=-0.176 \\
& S^{-1}=\left[\begin{array}{lll}
0.0125 & 0.0006 & 0.0016 \\
0.0006 & 0.0011 & 0.0003 \\
0.0016 & 0.0003 & 0.0019
\end{array}\right] \\
& T^{2}=\frac{n_{1} n_{2}}{n_{1}+n_{2}}\left(\bar{x}^{(1)}-\bar{x}^{(2)}\right)^{1} S^{-1}\left(\bar{x}^{(1)}-\bar{x}^{(2)}\right) \\
& T^{2}=\frac{7 \times 3}{7+3}(4.1821)=8.7824 \\
& F_{c a l}=\frac{n_{1}+n_{2}-p-1}{p\left(n_{1}+n_{2}-2\right)} \cdot T^{2} \\
& F_{c a l}=\frac{10-3-1}{3(10-2)} \times 8.7824=2.1956 \\
& F_{\text {tab }}=F_{3,6}(0.05)=4.76
\end{aligned}
$$

1) Hypothesis

$$
\text { Ho : } \bar{X}_{D, o}=\bar{X}_{D, n} \text { vs } \bar{X}_{D, o} \neq \bar{X}_{D, n}
$$

Since $F_{c a l}<F_{t a b}$, we accept Ho: and reject $\mathrm{H}_{1}$ : and conclude that there is no significant difference between the two means (the period before the introduction of TSA and the period after the introduction of TSA) on Liquidity Ration (L.R.), Capital Adequacy Ratio (C.A.R.) and Credit to customers in the Diamond Bank Nigeria Plc (Table 5, Table 6).

Also

$$
\begin{gathered}
\bar{X}_{B, o}=\left[\begin{array}{c}
116.04 \\
39.66 \\
1186.58
\end{array}\right] ; \quad \bar{X}_{B, n}=\left[\begin{array}{c}
112.17 \\
27.22 \\
1596.83
\end{array}\right] \\
\bar{X}_{B, o}-\bar{X}_{B, n}=\left[\begin{array}{c}
3.87 \\
12.44 \\
-410.25
\end{array}\right]
\end{gathered}
$$


Table 5. Data on the financial operations of First Bank Nigeria Ltd before TSA.

\begin{tabular}{cccc}
\hline \multicolumn{3}{c}{ First Bank Nigeria Limited } \\
\hline Year & L.R. (\%) $X_{1}$ & C.A.R. $(\%) X_{2}$ & Credit (M) $X_{3}$ \\
\hline 2007 & 108.831 & 30.7 & 222.2 \\
2008 & 137.63 & 69.7 & 476.4 \\
2009 & 118.64 & 47.19 & 752.2 \\
2010 & 121.03 & 31.8 & 1151.2 \\
2011 & 114.67 & 26.74 & 1366.8 \\
2012 & 110.46 & 22.45 & 1645.5 \\
2013 & 107.44 & 18.68 & 1841.4 \\
2014 & 109.6 & 20.05 & 2036.9 \\
\hline
\end{tabular}

Table 6. Data on the financial operations of First Bank Nigeria Ltd after TSA.

\begin{tabular}{cccc}
\hline \multicolumn{4}{c}{ First Bank Nigeria Limited } \\
\hline Year & L.R. (\%) $X_{1}$ & C.A.R. (\%) $X_{2}$ & Credit (M) $X_{3}$ \\
\hline 2015 & 110.69 & 28.49 & 1594.8 \\
2016 & 110.83 & 25.26 & 1897.2 \\
2017 & 114.98 & 27.9 & 1298.5 \\
\hline
\end{tabular}

$$
\begin{gathered}
\left(n_{1}-1\right) S_{1}^{2}=\left[\begin{array}{ccc}
693.58 & 1246.66 & -23629.10 \\
1246.66 & 5644.37 & 104.73 \\
-23629.10 & 104.73 & 3019.84
\end{array}\right] \\
\left(n_{2}-1\right) S_{2}^{2}=\left[\begin{array}{ccc}
9.64 & 1.26 & -1252.65 \\
1.26 & 5.37 & -809.86 \\
-1252.65 & -809.86 & 179.26
\end{array}\right] \\
\left(n_{1}+n_{2}-2\right) S=\left[\begin{array}{ccc}
703.22 & 1247.92 & -24881.75 \\
1247.92 & 5649.74 & -705.13 \\
-24881.75 & -705.13 & 3199.10
\end{array}\right] \\
S=\left[\begin{array}{ccc}
78.14 & 138.66 & 2764.64 \\
138.66 & 627.75 & -78.35 \\
2764.64 & -78.35 & 355.46
\end{array}\right] \\
\rho_{1.2}=\frac{138.66}{\sqrt{78.14 \times 627.75}}=0.626 \\
\rho_{1.3}=\frac{-2764.64}{\sqrt{78.14 \times 355.46}}=-0.880 \\
\rho_{2.3}=\frac{-78}{\sqrt{627.75 \times 355.46}}=-0.165 \\
S^{-1}= \\
{\left[\begin{array}{lll}
0.0000 & 0.0000 & -0.0004 \\
0.0000 & 0.00016 & 0.0001 \\
0.0004 & 0.00001 & 0.0000
\end{array}\right]}
\end{gathered}
$$




$$
\begin{gathered}
T^{2}=\frac{n_{1} n_{2}}{n_{1}+n_{2}}\left(\bar{x}^{(1)}-\bar{x}^{(2)}\right)^{1} S^{-1}\left(\bar{x}^{(1)}-\bar{x}^{(2)}\right) \\
T^{2}=\frac{8 \times 3}{8+3}(0.4727)=1.0313 \\
F_{c a l}=\frac{n_{1}+n_{2}-p-1}{p\left(n_{1}+n_{2}-2\right)} \cdot T^{2} \\
F_{c a l}=\frac{11-3-1}{3(11-2)} \times 1.0313=0.2674 \\
F_{t a b}=F_{3,7}(0.05)=4.35
\end{gathered}
$$

2) Hypothesis

$$
\text { Ho: } \bar{X}_{u, o}=\bar{X}_{u, n} \text { vs } \bar{X}_{u, o} \neq \bar{X}_{u, n}
$$

Since $F_{c a l}<F_{t a b}$, we accept Ho: and reject $\mathrm{H}_{1}$ : and conclude that there is no significant difference between the two means (the period before the introduction of TSA and the period after the introduction of TSA) on Liquidity Ration (L.R.), Capital Adequacy Ratio (C.A.R.) and Credit to customers of First Bank Nigeria Ltd.

The multivariate normal distribution for this problem is given bellow as;

$$
f(x)=(2 \pi)^{p / 2}|S|^{-1 / 2} \exp \left\{-1 / 2\left(\bar{X}_{1}-\bar{X}_{2}\right)^{\mathrm{T}} S^{-1}\left(\bar{X}_{1}-\bar{X}_{2}\right)\right\} ;-\infty<x<\infty
$$

where $p=3 ;|S|$ is the determinant of the respective pooled dispersion matrices from the respective banks; $\bar{X}_{1}=\left(\bar{X}_{D, o} ; \bar{X}_{B, o}\right)$ and $\bar{X}_{2}=\left(\bar{X}_{D, n} ; \bar{X}_{B, n}\right)$ and other symbols in the distribution retains their usual meaning as explained earlier. Hence, our model is a trivariate normal distribution.

\section{Conclusions}

In the analysis carrying out Diamond Bank Nigeria Plc and First Bank Nigeria Limited on the impact of TSA on the Banks' liquidity ration, capital adequacy and credit (availability) to customers, it was discovered that there were no significant differences between the period before and after the introduction of the TSA policy. In both cases, we accept the null hypothesis (Ho). These showed that there were no significant differences in liquidity ration; capital adequacy; and credit to the customers between the two periods on banks' performance.

Contrary to the speculations that TSA will affect banks' liquidity, capital adequacy and credit to customers, it was observed that the reverse was the case. Though TSA removes excess money banks collect from the floating government money which may affect other aspect of the banks' operation, there was no indication from our research that the introduction of TSA affects liquidity ratio, capital adequacy and credit. Irrespective of the perceived difficulties created by the introduction of TSA to banks in Nigeria, banks still put up their houses together and maintain a balance in these three parameters.

Finally, from the analysis on Diamond Bank Nigeria Plc, we observed that 
there were negative relationship between liquidity ratio and capital adequacy with correlation coefficient -0.093 , liquidity ratio and credit to customers with correlation coefficient -0.312 and between capital adequacy and credit to customers with correlation coefficient of -0.176 . On the other hand, from the analysis on first bank, we observed that there were both positive and strong relationships between the liquidity ratio and capital adequacy with correlation coefficient of 0.626; there was negative relationship between liquidity ratio and credit to customers with correlation coefficient of -0.880 and negative relationship between capital adequacy and credit to customers with correlation coefficient of -0.165 . The results from both banks were consistent. Finally, we established the distribution of the developed multivariate model for the problem under study.

\section{References}

[1] Kanu, C. (2016) Impact of Treasury Single Account on the Liquidity. ABC Journal of Advanced Research, 5, 43-52.

[2] Utsu, E.A., Mohammed M.B. and Obukeni, C.O. (2016) An Assessment of the Treasury Single Account Policy on Nigeria Economy. Social Sciences Journal of Policy Review and Development Strategies, 2.

[3] Yusuf, A. and Mohammed, S.B. (2016) Treasury Single Account (TSA) as an Effective Instrument of Financial Prudence and Management in Nigeria: Prospects and Problems. Nigerian Journal of Management Technology \& Development, 7.

[4] Oti, P.A., Igbeng, E and Obim, E.N. (2016) Appraisal of Policy Impact of Treasury Single Account in Nigeria. Research Journal of Finance and Accounting, 7, 45-52.

[5] Ndubuaku, V.C., Ohaegbu, O.K. and Nina, N.M. (2017) Impact of Treasury Single Account on the Performance of the Banking Sector in Nigeria. IOSR Journal of Economics and Finance, 8, 8-15.

[6] Ekubiat, J.U. and Ime, E.E. (2016) Adoption of Treasury Single Account (TSA) by State Governments of Nigeria: Benefits, Challenges and Prospects. Journal of Finance and Accounting, 4, 126-130. https://doi.org/10.11648/j.jfa.20160403.14

[7] Oguntodu, J.A. and Alalade, Y.S.A. (2016) Treasury Single Account and Nigeria's Economy between 1999 and 2015: An Assessment. Journal of Accounting and Financial Management, 2, 61-75.

[8] Arua, A.I., Chigbu, P.E., Chukwu, W.I.E., Ezekwem, C.C. and Okafor, F. C. (2000) Advanced Statistics for Higher Education. Academic Publishers, Nsukka.

[9] Onyeagu, S.I. (2003) First Course in Multivariate Statistical Analysis. Megaconcept Publishers, Awka. 